\title{
Evolution of the dwelling pattern in Urla: case study - Zafer Street
}

\author{
B. Şengün Erturgut \\ Department of Architecture Yasar University, Turkey
}

\begin{abstract}
This study focuses on the dwelling pattern in the historical town center of Urla, Izmir (Turkey). The purpose of this research is to examine the dwelling pattern and define the evolution of this pattern that occured during the Republican Period within the conservation context. Zafer Street is selected as a case study area because of its historical potential and location in the district. The historical town center of Urla attracts attention with its housing of 19th century. Historically, at the beginning of the 19th century, a cultural variety started in the town after the consistent migrations from Aegean Islands. Following the 19th century, as a result of the transformation that occured in social and economical conditions, the identical and architectural characteristics of the town went through a series of changes as well. After the Exchange Period, the changes in dwelling pattern continued increasingly following the proclamation of the Republic in Turkey. As a result, new restorations, worn-out houses and functional changes serving the new needs brought about reforms in the spatial orientation, facade characteristics and original structures of the old houses. The fourteen historical houses on Zafer Street are analyzed according to their original architectural characteristics. Since the Republican Period, alterations have been noticed in these fourteen houses. The changes that have been continued till today. With a detailed of analyses, this study is a list of recommendations to preserve Zafer Street and the houses on the street.

Keywords: the historical town center of Urla, İzmir (Turkey), dwelling pattern, change, conservation, Zafer Street.
\end{abstract}




\section{Introduction}

Historically, Urla the ancient site of the Ionian city of Klazomenai, played a significant role as the center of maritime and trade. At the beginning of the $19^{\text {th }}$ century, a cultural variety started in the town after the consistent migrations from Aegean Islands. Following the $19^{\text {th }}$ century, as a result of the transformation that occurred in social and economical conditions, the identical and architectural characteristics of the town went through a series of changes as well. After the Exchange Period, the changes that took place in dwelling pattern continued increasingly following the proclamation of the Republic in Turkey.

Zafer Street, a significant trade artery in the town center of Urla in the $19^{\text {th }}$ century, is a principal axle of the changes that the town went through in the Republican Period. The changes in contemporary life conditions, user needs, rising public interest in technology caused an increase in the intervention to the houses. In order to save the historical qualities of the town, it is necessary to preserve the original features of Zafer Street. In relation to that deduction, the purpose of this research is to examine the dwelling pattern which is a part of the cultural heritage in the historical town center of Urla and to analyze the changes that affected spatial orientation, structural and facade parameters of the houses on Zafer Street during the Republican Period. In addition, another goal of this study is to detect the conservation problems of the restored houses and recommend solutions.

\section{General information about Urla}

Urla is located at the center of Urla Peninsula which is known as the biggest Peninsula in Aegean Region (Mater [1]), fig. 1. Due to its geographical location,

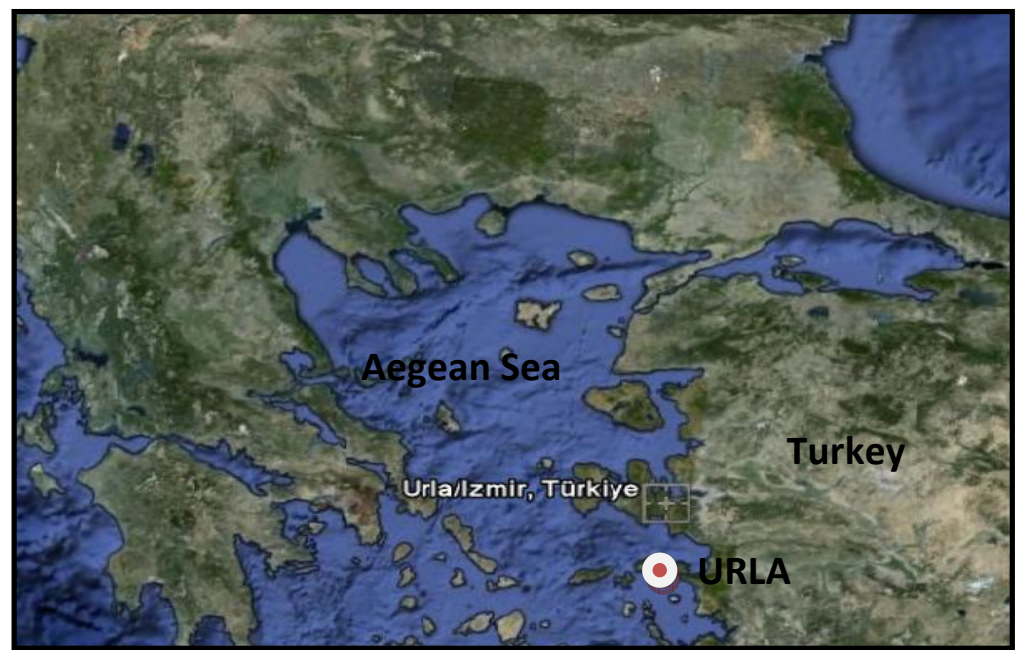

Figure 1: $\quad$ The place of Urla [2]. 
Urla Peninsula has the conditions of Mediterranean climate. Urla's area is $728 \mathrm{sq}$ $\mathrm{km}$ and the distance between city center and Izmir is $35 \mathrm{kms}$ (Mater [1]). According to results taken in National Population Census of the year 2000, Urla's population is 49.269. As a consequence of its climactic and floral characteristics, economy of Urla is based on agriculture. Even though agricultural land is of great importance as basic means of living, still there has been a decrease in the number of agricultural lands due to the excessive construction of secondary houses and tourism settlements.

\section{Historical development of Urla}

The history log of Urla streams to Prehistoric Period. According to the archeological heritage found in the excavation site of Liman Tepe, the history of the city goes back from the times of the Neolithic Age in 6000 B.C. to the Roman Period (Erkanal [3]). In Anatolian Seljuk Period, Çaka Bey seized Urla (Atay [4], Sevim [5]). In 1098, Izmir and Urla passed into the hands of the Byzantian Empire (Baykara [6]). In 1390, Aydin was seized by Ottoman Emperor Yildırım Beyazıt (Akın [7]). When the city was controlled by the Ottomans after 1426, in the course of time the city showed great progress in both land and sea trade (Baykara [6]). In the $15^{\text {th }}$ century, Izmir and Urla ports were busy with trade merely amongst Ottoman harbors (Kütükoğlu [8]). According to the population census of the $15^{\text {th }}$ century, Urla is more densely populated than Izmir during those years (Atay [9]). However during the $18^{\text {th }}$ century, Urla gradually lost its vitality in trade. Towards the end of the $18^{\text {th }}$ century, settlers in the island began to migrate to Urla Peninsula owing to the harsh living conditions on the island and this migration continued during the $19^{\text {th }}$ century as well. Rums, who came to the peninsula as labor force, gained the rights of Ottoman citizenship in the course of time and they settled in Urla (Atay [9]). In time they became rich land owners and the most prosperous social class in Urla. While Turks were the leading population at the beginning of the $19^{\text {th }}$ century, towards the end of the era, Rums became the leader in population (Baykara [10]). When the WWI started, in spite of all the resistance coming from Turkish Army, Greek Army forces marched into Urla on May $19^{\text {th }}$ (Coşar [11]). Following the recovery of Urla, Rums living on the peninsula were sent back to Greek and in turn Turkish citizens residing in Albania, Crete and Greek migrated to Urla (Tunçağ [12]). After the proclamation of Republic in 1923, Urla became a district of Izmir (Akın [7]).

\section{Analysis of the dwelling pattern in the historical town center of Urla}

The houses are densely populated on top of the hillside and they are mostly from $19^{\text {th }}$ century, fig. 2. Apart from the houses mainly used for living, ground floors of some of them on the street are used as shops and first floors of these houses are used as residences. Even though the houses where Turks and Rums live resemble one another in terms of their plans, still they differ in workmanship and 
materials. Since Rums had the advantages of being the prosperous class in the $19^{\text {th }}$ century, they paid significant attention and utmost importance to the architectural characteristics of their houses. Even though some buildings preserve their original housing functions, some have changed according to the needs and desires of the house-owners.

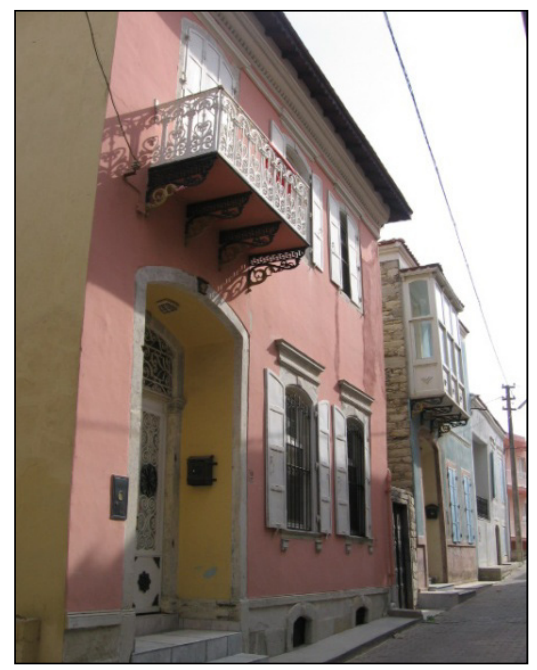

Figure 2: $\quad$ Historical houses in Urla.

In the historical town center, houses are classified into groups according to their plan schemes, as shown in table 1. Storey number, location of the halls and function of the spaces are taken into consideration while grouping the houses. According to this classification, five housing types and typology-out houses are listed. These are one-storey, centered-hall houses; two-storey, centered-hall houses; two-storey, centered-hall houses having commercial function; twostorey, side-hall houses; two-storey, side-hall houses having commercial function. Typology-out houses do not have a typical plan scheme or schemes.

Table 1: $\quad$ Plan schemes of the historical houses.

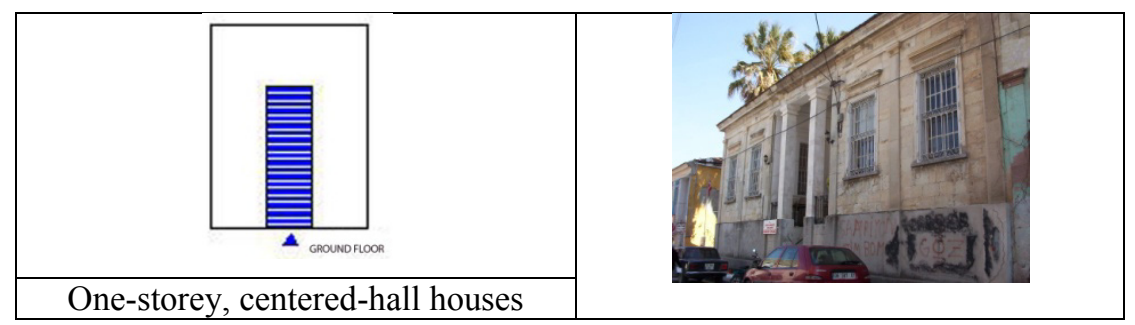


Table 1: $\quad$ Continued.

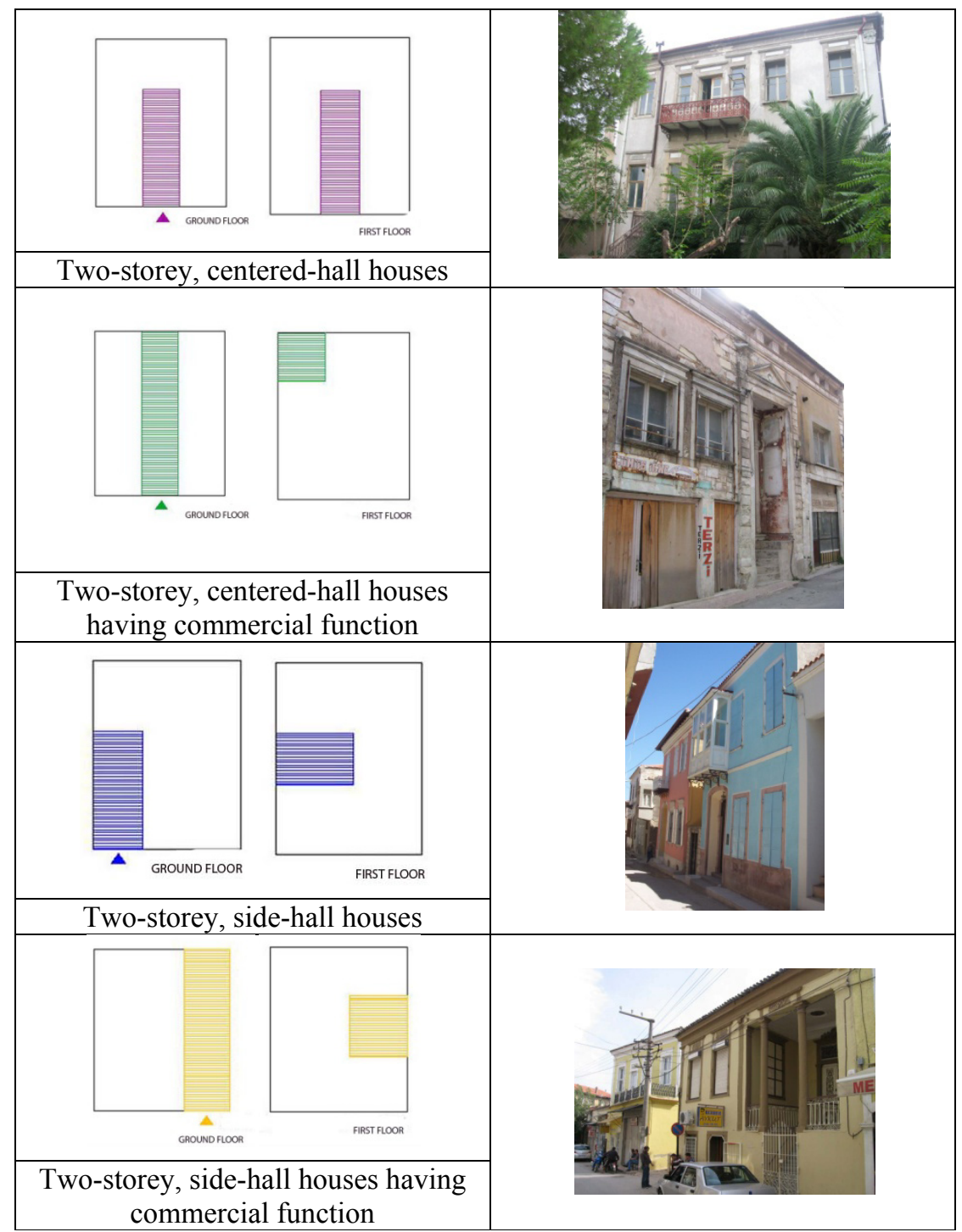

* Typology-out houses do not have a typical plan scheme

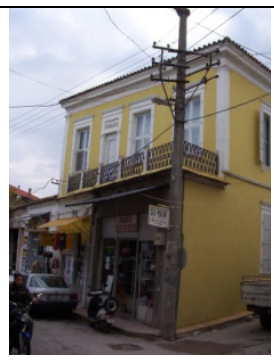


The houses do not differ in terms of their structural systems like their plan schemes. Load-bearing walls on the ground floor are massively constructed. Partition walls and first floor walls in two-storey houses are structured in skeleton construction. Wooden slab is used on the ground and first floors. Parallel with the plan typologies, it has been found out that those facades of the historical houses change according to the storey numbers, location of the halls, and commercial functions of the buildings. Aside from the door and window, houses in the historical town center have also bay window, balcony, fringe and cincture.

\section{Analysis the dwelling pattern of Zafer Street}

Zafer Street's Greek name was "Fardi Street" on the $19^{\text {th }}$ century, figs. 3 and 4 . It has a rich cultural heritage and also commercial functions (Milioris [13]). Since it was the main commerce center of the town, the street preserves the house types that have both housing and commercial functions all together. On the street, aside from two-storey, centered-hall house types, four typology and typology-out house samples are listed. At the present time, twenty-five houses on the street are protected by Board of the Conservation of the Cultural and Natural Heritage. Eleven of them are shops, two of them are houses and twelve of them are houseshops.

Fourteen historical houses on Zafer Street lost their historical characteristics in the course of time according to the needs of their users and changes that happen in time. Changes of the houses are related to the repair works that arise from the desires of the owners because of the wearing outs and damages that occur. Consequently some physical changes can be seen in the structures of the houses. These changes can be observed in the spatial orientations, structures, materials and facades of the houses.

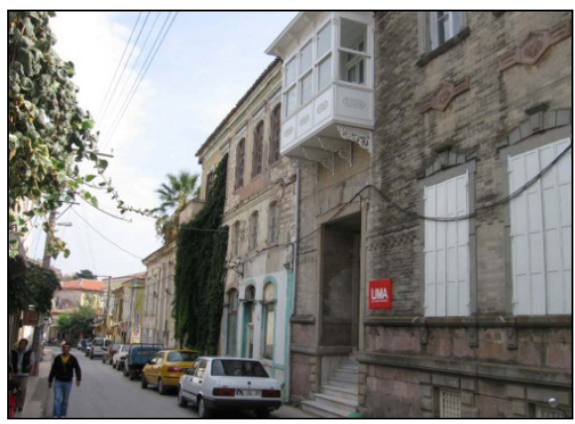

Figure 3: $\quad$ Zafer Street. 


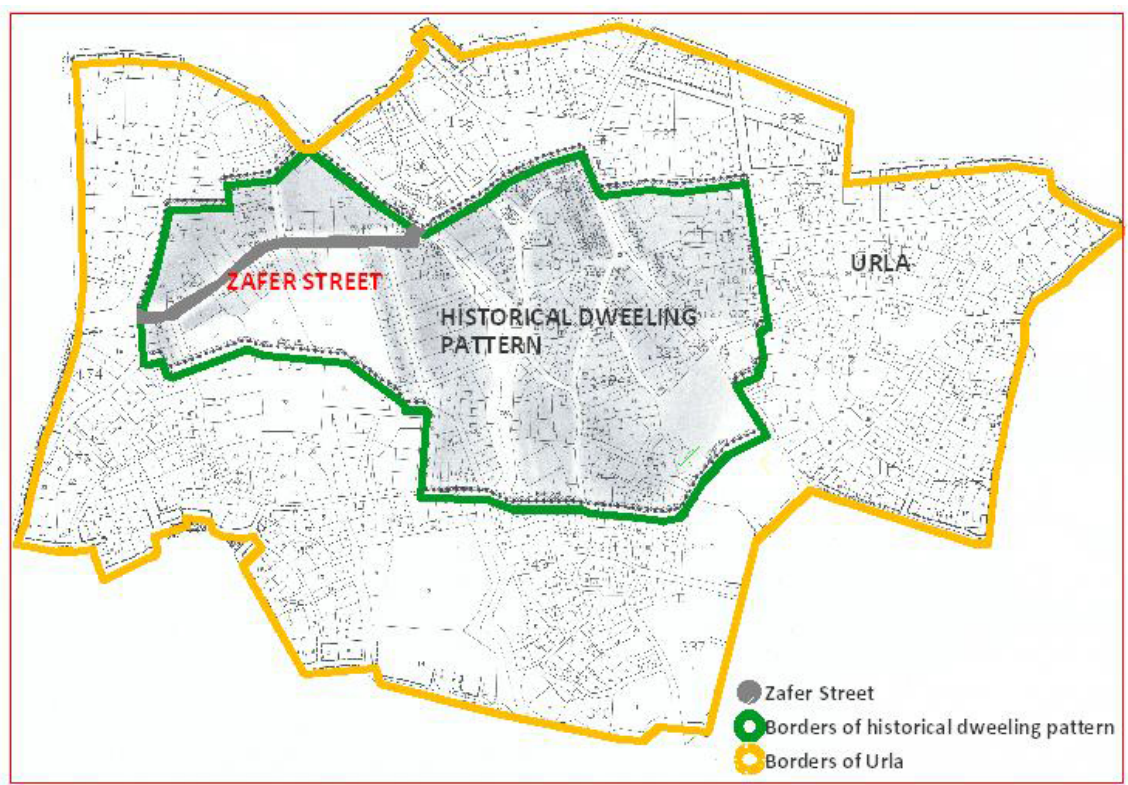

Figure 4: The place of Zafer Street in Urla.

\subsection{Evaluation of the changes that occurred in the houses on Zafer Street}

The basic factor that affects the physical changes in the spatial characteristics of the houses is related to the needs and restoration desires of the owners. While scanning the inner structures of the fourteen houses, some physical changes such as mass additions, fig. 5, adding-dropping partition walls and omission of the stairway have been detected, fig. 6. Mass addition has been seen in nine houses, partition wall is added to five houses. Partition walls have been demolished in.

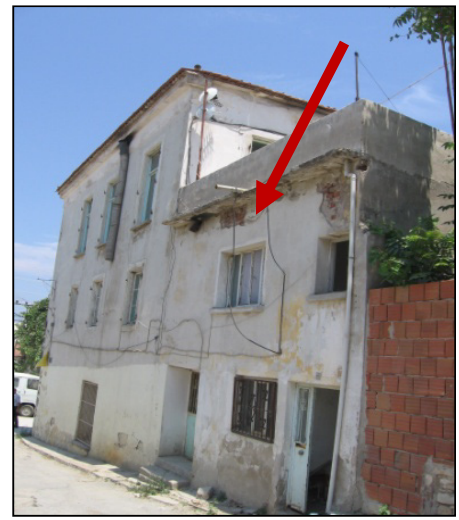

Figure 5: Mass additional. 


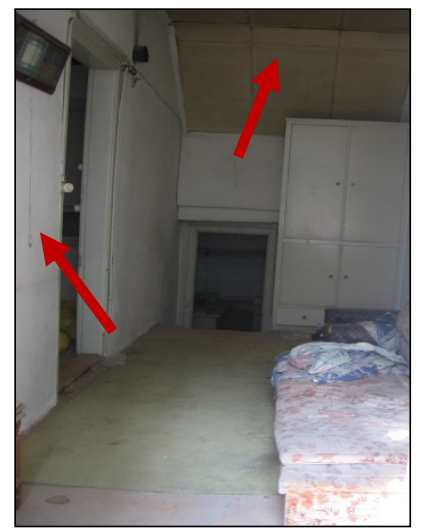

Figure 6: Addition of a partition wall and eliminated wooden stair.

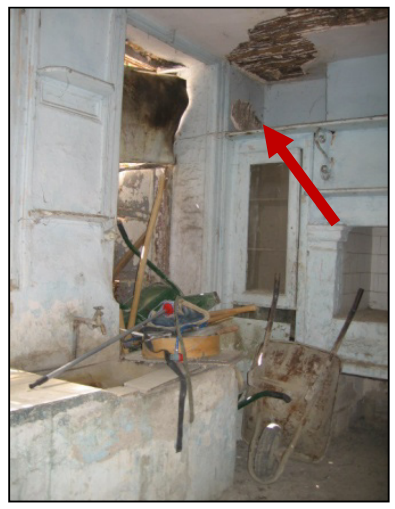

Figure 7: $\quad$ Out-of-use space and deterioration of the wall.

one house. Original wooden stairs have been eliminated in three houses, fig. 6 Also in ten houses some areas have been become out-of-use spaces like kitchen, fig. 7.

In the study based on the structural and material changes of the fourteen historical houses, deterioration in structural elements resulting from oldness, fig. 7, addition of concrete system and changing of ceiling/slab materials have been determined. During the repair processes of the two houses, the wooden stairs which provided the circulation between floors are changed to concrete stairs as a result of the owner's desire, fig. 8. In ten houses ceiling and slab materials are renewed because of oldness and owner desires.

In the studies carried out on the street, it has been observed that in the facades of the houses, elements are changed according to the desires of the house owners. These changes are addition of new hardware, change in roofing tile, material and color change, bay window-balcony change, woodwork change, deterioration of the plaster. In the houses, it has been seen that sign, electrical 
cable, illumination members and shutters are added into the facade, fig. 9. Two houses which had shops on the ground floor have been changed their windows to vitrines. In the repair of the eight structures, Marsilian roofing tile is used instead of Turkish style roofing tile. Color change is observed in seven houses. Material changes are detected in two bay windows and one balcony. Wooden windows or doors have been replaced with plastic or aluminum windows in ten houses, fig. 10. Some deterioration has been observed in plaster surfaces of the twelve houses.

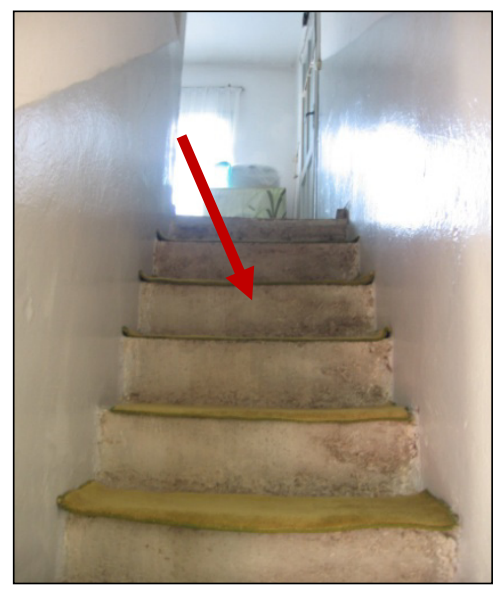

Figure 8: $\quad$ Concrete stairs.

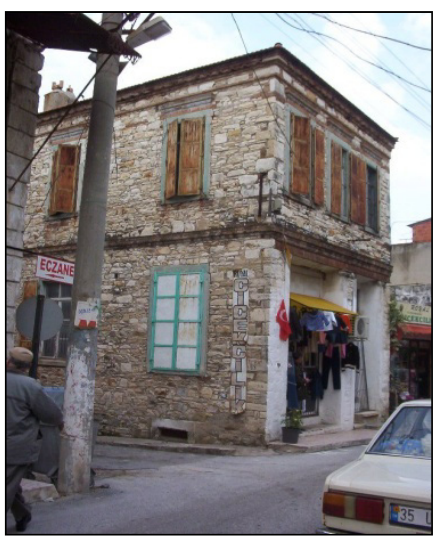

Figure 9: $\quad$ Addition of new hardware. 


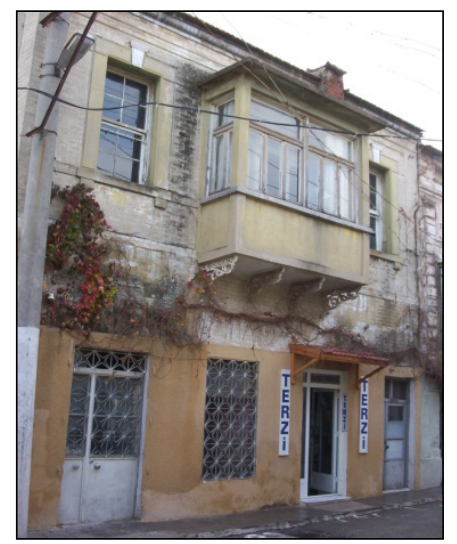

Figure 10: Change of the ground floor wood work.

\section{Conservation problems of the houses on Zafer Street and suggestions}

The problems that threaten the houses on Zafer Street have been detected with the help of the analyzes. In this part, solutions to the problems of the houses will be suggested.

\subsection{Conservation problems of the houses on Zafer Street}

Since the Republican Period, there are several problems that can be noted on Zafer Street. Mass addition is determined in nine houses on Zafer Street. Mass addition is especially for wet spaces and generally these are seen at the back side of the houses which worsen the original appearance of the houses. It has also been observed that some of the houses on Zafer Street are broken by partition wall additions or eliminations in order to create extra or wider spaces. Wooden stairs that enable circulation between floors have been eliminated in two twostorey, side-hall houses having commercial function and one typology-out house. This causes a breakdown in both circulation axle and spatial orientation of the building. Two-storey, centered-hall houses having commercial functions are used as shops and the space left on the first floor is inadequate to the use of the dwellers today. Since the dwellers prefer comfortable new houses, historical buildings are deserted or not preferred. Alongside with the abandoned buildings, there are some out-of-use houses too on Zafer Street. They are either worn-out or deserted by their owners. While repairing the houses, wooden stairs are exchanged for concrete stairs, original ceilings and slab materials are changed. In the structural elements of the houses some cracks on the walls and rotation on the wooden materials occur due to the oldness or earthquakes. This causes destruction in the original structure system of the houses. Facade changes cause transformations in the visual sensations of the houses and elimination of the original cause problems. 


\subsection{Suggestions to conserve the houses on Zafer Street}

The basic purpose of the suggestions is to protect the houses on the street and to expose the historical and architectural values of the street. In addition to protect these values, the transfer of these houses to the next generations and modifications of them to modern life is also aimed. While making these suggestions, the changes in the spatial orientations of the houses, structural and facade changes have been taken into consideration. The houses that have commercial functions are the ones that need most mass additions on Zafer Street. Inner design of these houses should be handled. It is suggested that partition wall additions that are made improperly should be turned into their original forms. Wooden stairs that have eliminated in three houses for different reasons should be changed into their authentic forms. The houses that will have functional changes should be transformed in accordance with plan typologies and spatial orientations. In houses that having commercial functions, when the house no longer serves the needs of the dwellers the family should be moved to an empty historical house. Four out-of-typology houses on the street should be nationalized before they lose their historical heritage. These houses should be allocated to the families in need or should be served as the social and cultural centers after agreeing with the first owners of these houses. Wooden stairs that have been changed with concrete stairs, renewed ceilings and slabs should be repaired if possible and used. If they cannot be fixed, old and new materials should be separated. The houses should be strengthened with additional supportive elements. Cracks that are observed in the structural elements should be clamped and sewed. Conservation of the original facade characteristics of the historical houses is vitally important. The original facade characteristics enable a fullness of visual aspect and original architectural features of the facade are well seen.

\section{Conclusion and evaluations}

Since the Republican Period, some changes occurred in dwelling pattern and houses themselves. When its historical potential in the town center is taken into consideration, Zafer Street is a significant axle that reflects the changes in building scale. The changes that emerge in dwelling pattern bring problems: The loss of the commercial importance of Zafer Street; the decline in the historical characteristics of the houses; careless restructuring cause a breakdown in the integrity. House dwellers who want to keep abreast of the new technology and life conditions make changes in the spatial orientation, structural, material and facade organizations of the houses. Restorations in the historical houses should be made in accordance with the related data and documents. In the studies made to conserve the original house, the primary aim is to conserve the cultural heritage of the historical houses and transfer their original forms to the next generations. 


\section{References}

[1] Mater, B., Urla Yarımadası'nda Arazinin Sinıflandirılması ile Kullanısı Arasındaki ilişkiler. Edebiyat Fakültesi Matbaası: İstanbul, pp. 56-57, 1982.

[2] Maps.google.com

[3] Erkanal, H., Liman Tepe Kazıları. İzmir Kent Kültürü Dergisi, pp. 221-227, 2002.

[4] Atay, Ç., Tarih Içinde İzmir, Tifset B. ve Y. A.Ş.: İzmir, pp. 77-78, 1978.

[5] Sevim, A., Anadolu'nun Fethi Selçuklular Dönemi, Türk Tarih Kurumu Basımevi: Ankara, 32-36, 1988.

[6] Baykara, T., İmir Şehri ve Tarihi, Ege Üniversitesi Matbaası: İzmir, 1974.

[7] Akın, H, Aydınoğulları Hakkında Bir Araştırma, Ankara Üniversitesi Basımevi: Ankara, pp. 87, 1968.

[8] Kütükoğlu, M., Osmanlı Dis Ticaretinin Gelişmesinde İzmir Limanı ve Gümrüklerinin Rolü, İzmir Ticaret Odası Sempozyumu, 1985.

[9] Atay, Ç., Kapanan Kapılar: İzmir Hanları, İzmir Büyükşehir Belediyesi Kültür Yayını: İzmir, pp. 101-103, 2003.

[10] Baykara, T., Türk Devrinde Urla Kazası 1080 -1980, Ege Üniversitesi: İzmir, pp. 52-54, 1991.

[11] Coşar, Ö. S., Yunanlılara Silahlı Mukavemet Başladı, İstanbul Harbi Gazetesi, 4(4), Yeni İstanbul Yayını: İstanbul, pp.1, 1919.

[12] Tunçağ, A. S., Bir Varmıs Urla, Stil Matbaacılık: İzmir, pp. 16-18, 2003.

[13] Milioris, N.E., 1922 Öncesinde Urla, Urla Belediyesi Yayınları, pp. 45-47, 2002. 